\title{
Female condom in HIV/AIDS prention among female commercial sex workers in Nigeria: a geographical perspective
}

\author{
Emmanuella Onyenechere
}

From $16^{\text {th }}$ International Symposium on HIV and Emerging Infectious Diseases

Marseille, France. 24-26 March 2010

\section{Background}

One of the primary concerns of the Millennium Development Goals is to combat and reverse the spread of the HIV/AIDS. An estimated three million people in Nigeria live with AIDS, and current research suggests that unprotected sex accounts for about 90 per cent of the infections among adolescent girls, economically disadvantaged women and commercial sex workers who constitute the high risk group. The paper considers more effective and equitable ways to contain the spread of the virus, especially among the socially excluded group of female commercial sex workers in Nigeria.

\section{Methods}

The paper is based on a survey of about 1,500 brothel based commercial sex workers who responded to a questionnaire designed to elicit information on the extent of infection among them, and on current attitudes and measures to control the spread of the pandemic in four major geographical zones of Nigeria selected for the study. Government officials and health representatives were also interviewed on how existing laws protect the rights and welfare of CSWs, and the programmes of government and its development partners to promote the use of female condoms and on other measures to control the AIDS pandemic. Secondary sources were consulted for theoretical and comparative insights on the spatial and behavioral aspects of disease and health, and on the merits and limitations of condom use in Southern Africa and elsewhere. Maps and charts are used where necessary to illustrate spatial variations.

\section{Results}

The study confirms that female commercial sex workers suffer discrimination and neglect, and have limited access to information on the new devises and other resources available to reduce and treat HIV infections. It argues that since women appear to be in a subordinate position in sexual relations with men, the female condom, over which the women have greater control, is for them the only safe-sex method available, and should therefore constitute an essential component of any strategy for contraception, microbicide and AIDS prevention. I calls for a well designed and properly targeted government intervention that would subsidize the high cost of female condoms, and promote its accessibility and use among commercial sex workers.

\section{Discussion}

The paper concludes with some general reflections on the implications of the study for public policy, and on how the geographer can contribute to a better understanding of the spatial incidence and spread of disease, and the optimal and equitable location of health programmes and interventions.

Published: 11 May 2010

doi:10.1186/1742-4690-7-S1-P118

Cite this article as: Onyenechere: Female condom in HIV/AIDS prention among female commercial sex workers in Nigeria: a geographical perspective. Retrovirology 2010 7(Suppl 1):P118. 